\title{
KAI KOSKELA
}

\section{KAATUI KOTONAAN JA KUOLI!}

\author{
Valtio terveyskasvattajana
}

Vanhus kaatui yöllä kotonaan ja kuoli. Murheellinen juttu. Alku ja loppu aiheelle valtio terveyskasvattajana. On siis aloitettava mummun kuolinyöstä.

Yöllä kahden ja kolmen välillä iski pissahätä. Iän myötä ja etenkin lääkkeiden vaikutuksesta kun tahtoo yölläkin pissattaa. Mummo nousi sängystä ja lähti tutussa kodissaan kohti vessaa. Matot olivat kauniisti paikoillaan ja niiden alla liukuesteet, joten niihin hän ei kompastunut. Yölamppukin toimi. Lyhyellä matkalla vessaan ei ollut vieraita esineitä tai tuntemattomia kulmia. Lattia oli puhdas, mutta ei liukkaaksi vahattu. Silmälasit löytyivät ja olivat oikean vahvuiset. Kauppias oli aivan oikein suositellut mummulle hyväpohjaiset aamutossut. Ja kuitenkin kaikkien hämmästykseksi mummu kaatui. Arkiset ovat valtiollisen terveyskasvatuksen lähtökohdat.

Iän myötä, ravitsemuksellisista puutteista johtuen tai vaikkapa käytettyjen lääkkeiden vaikutuksesta mummun tasapainon säätelyjärjestelmät olivat hidastuneet. Nopean liikkeellelähdön vuoksi ne eivät ehtineet riittävän nopeasti toimia. Seurauksena oli voimakas huimaus ja kaatuminen. Eikä vanhuksellamme ollut edes mummun tuuria; olisi katkennut vain vastaanottavan käden ranteen luu. Luun haurastumisen, osteoporoosin seurauksena luuston kestokyky on kuitenkin heikko ja nyt katkesi tavanomaiseen tapaan reisiluun kaula. Kädessä ei ole ranneketta, jolla voisi saada yhteyden kotisairaanhoidon tai kotipalvelun päivystykseen. Verenhukka oli suuri ja mummu menehtyi. Näinkin ihminen voi kuolla.
Terveyskasvattaja ihmettelee kuoliko mummu tietämättömyyttään tai uhkarohkeutensa takia, ohjeiden tai neuvojen puutteeseen, yleensä huonokuntoisuuttaan vai epätarkan lääkityksen takia. Ympäristökö oli kaiken syynä vai apuvälineiden puute? Olisiko tapaturman ehkäisemiseksi ollut tehtävissä mitään? Miksi ihmeessä mummu ei edes siunannut itseään istuallaan ennen liikkeelle lähtöä? Se olisi jo antanut aikaa tasapainojärjestelmille.

Vastaava kuoleman paikka olisi voinut olla vessa. Pissaaminen sinänsä saattaa vanhalla ihmisellä autonomisen hermoston kautta häriöittää tasapainoa, aiheuttaa huimausta ja lisätä kaatumisriskiä. Kaikki tämä varsinkin mikäli vanhuksella ei olisi ollut korotettua vessanpönttöistuinta, liukastusestettä lattialla ja pöntön vieressä kunnollista tarttumiskahvaa. Entä kotipihalla; kysyisimme tietysti hiekoituksesta, kunnollisista talvikengistä, kävelykepistä, valaistuksesta, kynnyksistä ja kaiteista. Terveyskasvattajan näkökulmasta vanhuksen kuolemassa olivat mukana lähiomaiset, lääkärit ja hoitajat, talonmiehet ja isännöitsijät, kotipalveluhenkilöstö, kenkäkauppiaat, rakennussuunnittelijat, lainlaatijat ja ketkä vielä? Mahtoivatkohan edes tietää vastuustaan?

\section{Vakavat onnettomuudet kodeissa lisääntyneet jyrkästi}

Terveyskasvatus lähtee yksilöstä, hänen mahdollisuuksistaan elää onnellinen ja turvallinen elämä. Sitten perhe, ryhmät ja koko väestö. Ainutkertainen mummu ja hänen kuolemansa saa valtakunnallisen kehyksen. 
Suomessa tapahtuu vuosittain noin 750000 tapaturmaa. Ne aiheuttavat vuosittain sairaanhoitomenoja, työpäivätappioita ja monenlaisia muita kuluja $25-30$ miljardia markkaa. Tapaturmista noin kaksi kolmasosaa on koti- ja vapaa-ajan tapaturmia. Viime vuosina koti- ja vapaa-ajan tapaturmiin on kuollut noin 2100 henkilöä vuodessa, liikennetapaturmiin 600 ja työtapaturmiin 100 henkeä. Kuolemaan johtaneet liikenneonnettomuudet ja työtapaturmat on Suomessa onnistuttu 10 vuodessa puolittamaan, mutta koti- ja vapaa-ajan tapaturmien kohdalla kehitys kulkee täysin päinvastaiseen suuntaan. Vakavien, kuolemaan johtaneiden tapaturmien osuus on vajaan 10 vuoden aikana lisääntynyt 40 prosenttia.

Tapaturma on aina tahaton, odottamaton ja äkillinen tapahtuma. Tapaturmien syyt ovat monet: tapaturmaan altistavalle ympäristölle on tyypillistä vieraus ja vaikeus, ympäristön yllättävä muutos ja ylivirikkeisyys. Monet välineet taas voivat olla outoja, kankeita, rikkinäisiä tai epäkäytännöllisiä, myrkyllisiä tai varustettu väärillä ohjeilla ja tiedoilla. Tapaturmaan voi altistaa myös tietenkin ihmisen havaintokyvyn heikkeneminen, kokemattomuus, harjoituksen puute, väärä oppimistapa, asenne, mieliala tai halu ottaa riskejä. Tuloksena on tapaturma joka aina aiheuttaa pelkoa, on epämieluisa ja johtaa kipuun ja kärsimykseen.

Yksinään kotitapaturmissa kuolee vuosittain lähes tuhat henkeä. Hoitotarve on vastaavasti niin suuri, että siihen joudutaan varaamaan ison noin 1000 sairaalapaikkaa omaavan yliopistollisen keskussairaalan kaikki vuodepaikat ympärivuotisesti. Vuotuiset työpanostappiot ovat noin 600 miljoonaa markkaa ja kotitapaturmien hoidon kustannukset noin 700 miljoonaa markkaa vuodessa. Valtionkin rahoissa pitkä penni.

Myrkytyksiä, kaatumisia, putoamisia, liukastumisia, palovammoja, kone- ja laitevammoja, näitähän nämä kodin tapaturmat pääasiallisesti ovat. Ylivoimaisesti suurin ja nopeasti vaikeutuva ryhmä ovat vanhusten kaatumiset ja putoamiset, joihin vuosittain yli 400 vanhusta menehtyy. Kolmasosa yli 65-vuotiaista kaatuu kotonaan. 5 - 7 prosentilla murtaa luun. Reisiluun kaulan murtumia on yli 2000 vuodessa. Onneksi ne nykyisin useimmiten saadaan kirurgisesti hoidettua. Tässä siis esimerkkivanhuksemme kuoliaaksi kaatunut mummu kanssasiskojen/veljien kanssa terveyskasvattajan valtakunnallisena ongelmana. Esimerkkinä terveyspoliittisesta ongelmasta, jonka ehkäisystä emme toistaiseksi voi kertoa menestystarinaa. Mitä siis valtion terveyskasvattaja yritti ja yrittää tehdä? Parhaansa tietenkin!

\section{Mitä valtion terveyskasvattaja teki?}

1970-luvun puolivälissä kodin tapaturmien mittasuhteesta ei oikeastaan tiennyt kukaan muu kuin kirurgisen osaston lääkärit ja hoitajat: hoitopaikat täyttyivät käden tai jalan katkaisseista vanhuksista. Tämä tietämättömyys johtui $\mathrm{mm}$. siitä, että tutkimusperinne alalla oli heikkoa, seurantajärjestelmät rakentamatta, puuttui lainsäädäntö, työntekijät, torjuntatyötä tekevät organisaatiot ja rahaa. Liikenne- ja työtapaturmien puolella nämä edellytykset olivat jo vuosikymmenien takaa. Valtion terveyskasvattaja ei suinkaan ensimmäiseksi rynnännyt kadulle kansanvalistajaksi vaan keskittyi kunnollisen epidemiologisen tilanneselvityksen ja ennusteen tuottamiseen, tapaturmalajien ja syiden erittelyyn, kustannusten kartoittamiseen sekä jo kertyneen käytettävissä olevan tiedon ja osaamisen analysointiin. 1970-luvun lopulla osattiin jo kertoa ongelman järkyttävä laajuus sekä tiedot nopeasti pahenevasta tilanteesta. Samanaikaisesti kasvatus- ja neuvontatyö suunnattiin lainsäätäjiin ja poliitikkoihin ja esitettiin valtakunnallisen ehkäisy-yksikön perustamista. Ei saatu takkia, mutta sentään liivit ja näin valtioneuvosto asetti ensimmäisen koti- ja vapaa-ajan tapaturmien neuvottelukunnan, joka laati nopeasti ensimmäisen kolmivuotisen valtakunnallisen kotitapaturmien ehkäisysuunnitelman. Ongelma oli

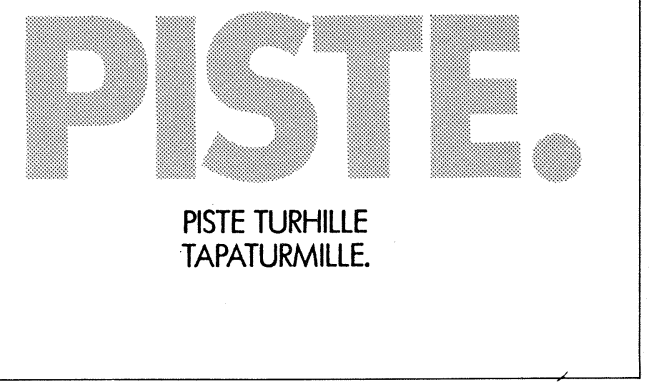


siis jotenkin kartoitettu ja esitykset työnjaosta ja jatkotoimenpiteistä tehty. Suunnitelmasta saatu palaute oli hyvä. Se johti useisiin käytännön toimenpiteisiin. Uusi suunnitelma valmistui seuraavaksi kolmivuotiskaudeksi.

Terveyskasvattajan työ ei kuitenkaan ole pelkkää tutkimista ja suunnitelmapapereiden tekemistä vaan myös käytännön ehkäisyohjelmien kehittämistä ja valtakunnallista toteuttamista. Laajana viranomaisten ja vapaaehtoisten järjestöjen yhteistyöohjelmana käynnistettiin valtakunnallinen 'piste turhille tapaturmille' -ohjelma: Valmistettiin opetusaineistoja tuhansiin terveyden- ja sosiaalihuollon laitoksiin ja kouluihin, koulutettiin kymmeniätuhansia työntekijöitä, valmistettiin videoita sekä radio- ja televisio-ohjelmaa lähetettäväksi yhteistyössä eri tiedotusvälineiden kanssa.

Samanaikaisesti neuvoteltiin kenkäteollisuuden kanssa turvallisen kengän standardeista ja markkinoinnista erityisesti vanhusväestölle, elvytettiin kävelykepin käyttöä, konsultoitiin apteekkeja ja lääketeollisuutta lääkeinformaation parantamiseksi, uusittiin sairaanhoito- ja kotipalveluyksiköiden ravitsemussuositukset ja niissä tarjottavan ravinnon sisältö, neuvoteltiin apuvälinetuottajien kanssa tapaturmia ehkäisevien apuvälineiden kehittämistyöstä, käynnistettiin kampanjoita rikkinäisten tavaroiden ja lappujen korjaamiseksi ja erilaisten tarttumakahvojen asentamiseksi ja annettiin suosituksia $\mathrm{mm}$. taloyhtiöille hiekoituksen järjestämiseksi. Pitkä lista.

Rakennusstandardimme on tehty hyväkuntoisen aikuisen lähtökohdista. Lapselle ja vanhukselle normaali voi olla mittakaavavirhe. Terveyskasvattaja kaipaa lainsäätäjää ja rakentamisen valvojaa. Rakennuslain uudistaminen onkin nyt etulinja-asiaa.

Tällaista tämä valtion terveyskasvattajan valtiollinen työ. Kaiken perustana on terveysongelmien epidemiologia ja ennuste. Seuraavassa vaiheessa tulisi pystyä eri ongelmien osalta arvioimaan mikä osuus niistä on ratkaistavissa erityisesti ehkäisyn ja tarkemmin kasvatuksen ja neuvonnan keinoin. Kun terveyskasvatus on viime vuosina laajentunut laajaksi terveyden edistämistyöksi, on myös toiminta-ala ja mahdollisuudet moninkertaistuneet. Kun perusneuvonta ja perustieto on väestöryhmille turvattu, vastuu tutkimuksesta, seurannasta sekä torjuntatoimenpiteistä selkeästi eri tahoille osoitettu, työnjako sovittu, kun lainsäädännöllä on rakennettu ehkäisevän työn puitteet ja kun henkilöstö- ja muut resurssit on turvattu pitkäjänteiseen työhön, voi valtion terveyskasvattaja perustellusti odottaa rohkaisevia tuloksia. Yhä harvempi vanhus menehtyy tapaturmiin.

Kaatui kotonaan ja kuoli. Esimerkki, joka sai terveyskasvattajan toimimaan. Sosiaali- ja terveyshallituksen terveyden edistämisestä, terveyskasvatuksesta ja sosiaalisesta selviytymisestä vastaava yksikkö on vuodelle 1992 - 93 vahvistanut koti- ja vapaa-ajantapaturmien ehkäisyn lisäksi painoalueekseen nuorten tupakoinnin ja päihdehaittojen vähentämisen, haavoittavissa elinoloissa olevien lasten ja nuorten selviytymisen parantamisen, laman terveydellisten haittojen selvittämisen, tartuntatautien, erityisesti aidsin tehokkaan torjunnan sekä sosiaali- ja terveysnäkökohtien paremman välittämisen yhdyskuntasuunnitteluun. Kaikkien näiden painoalueiden takaa löytyy vanhuksemme kaltaisia tarinoita.

Jotta mahdollisimman moni terveyden ja sairauden tarinoista saisi onnellisen lopun on painoalojen tavoitteiden saavuttamiseksi valmistauduttu vuosittain toteuttamaan $30-40$ tutkimusta, $30-40$ paikallista ja valtakunnallista kehittämishanketta sekä sata erilaista koulutuskokonaisuutta. Yksikkö tuottaa lisäksi kymmeniä tunteja radio- ja televisio-ohjelmaa, useita opetuskokonaisuuksia lastentarhoihin, kouluihin, työpaikoille sekä sosiaali- ja terveydenhuollon yksiköihin, valmistelee esityksiä eri viranomaisille lainsäädännön uudistamiseksi, sekä toteuttaa neuvotteluin ja yhteistoiminnalla vapaaehtoisten järjestöjen ja elinkeinoelämän kanssa tiedollisia, tuotantoteknisiä ja rakenteellisia uudistuksia terveyttä edistävien valinnanmahdollisuuksien parantamiseksi.

PS. Ajattelin vielä pissahätäistä mummua. Sama hätä joka yö, monta kertaa. Ennen vanhaan oli potta, joka ei sellaisenaan ole kovin käyttökelpoinen. Kunpa saisi kehitetyksi kevyen, yöpöydälle mahtuvan, naiselle sopivan yöastian. Olen kuullut, että joku on ideoinut. Tämän hankkeen tukeminen olisi varmaankin valtion terveyskasvattajan tehtävä. Isänmaallinen teko! 